\title{
The direct impact of landslides on household income in tropical regions: a case study from the Rwenzori Mountains in Uganda
}

\author{
K. Mertens ${ }^{1 *}$, L. Jacobs ${ }^{2}$, J. Maes ${ }^{1,2}$, C. Kabaseke ${ }^{3}$,M. Maertens ${ }^{1}$, J. Poesen ${ }^{1}$, M. Kervyn ${ }^{2}$, L. Vranken ${ }^{1}$ \\ ${ }^{1}$ Department of Earth and Environmental sciences, KU Leuven, Geo-instituut, Celestijnenlaan 200E, B- \\ 3001 Leuven-Heverlee \\ ${ }^{2}$ Department of Geography, Vrije Universiteit Brussel, Pleinlaan 2, B-1050 Brussels \\ ${ }^{3}$ School of Agricultural and Environmental Sciences, Mountains of the Moon University, Fort Portal, \\ Uganda \\ * Corresponding author: Kewanmertens@hotmail.be
}

\begin{abstract}
Landslides affect millions of people worldwide, but theoretical and empirical studies on the impact of landslides remain scarce, especially in Sub-Saharan Africa. This study proposes and applies a method to estimate the direct impact of landslides on household income and to investigate the presence of specific risk sharing and mitigation strategies towards landslides in a tropical and rural environment. An original cross-sectional household survey is used in combination with geographical data to acquire detailed information on livelihoods and on hazards in the Rwenzori mountains, Uganda. Ordinary least squares regressions and probit estimations with village fixed effects are used to estimate the impact of landslides and the presence of mitigation strategies. Geographical information at household level allows to disentangle the direct impact from the indirect effects of landslides. We show that the income of affected households is substantially reduced during the first years after a landslide has occurred. We find that members of recently affected households participate more in wageemployment or in self-employed activities, presumably to address income losses following a landslide. Yet, we see that these jobs do not provide sufficient revenue to compensate for the loss of income from agriculture. Given that landslides cause localized shocks, finding a significant direct impact in our study indicates that no adequate risk sharing mechanisms are in place in the Rwenzori sub-region. These insights are used to derive policy recommendations for alleviating the impact of landslides in the region. By quantifying the direct impact of landslides on household income in an agricultural context in Africa this study draws the attention towards a problem that has been broadly underestimated so far and provides a sound scientific base for disaster risk reduction in the region. Both the methodology and the findings of this research are applicable to other tropical regions with high landslide densities.
\end{abstract}

Impact assessment, landslide, household income, quantitative survey, Sub-Saharan Africa, Uganda 


\section{Introduction}

Disasters have an important impact on economic development. They disrupt livelihoods, cause loss of human lives and damages to properties and infrastructure are estimated to cost around USD 250 billion worldwide each year (Okuyama \& Sahin, 2009; UNISDR, 2015). This impact is expected to increase due to the increasing occupation of marginal land and changing weather patterns related to climate change (Mendelsohn \& Saher, 2010). While the absolute monetary damage caused by disasters is larger in high-income countries, the absolute number of fatalities and the relative damage as a share of GDP is largest in low- and middle income countries (Kahn, 2005; Okuyama \& Sahin, 2009; Toya \& Skidmore, 2007; UNISDR, 2015).

Landslides contribute directly or indirectly to about $17 \%$ of all disaster-related fatalities worldwide and rank as the $7^{\text {th }}$ most killing natural hazard (Lacasse $\&$ Nadim, 2009; Petley, 2012). They are defined as 'the movement of a mass of rock, debris or earth down a slope' and mostly constitute small, but sometimes frequent events affecting millions of people worldwide (Cruden \& Varnes, 1996). Landslides occur when triggering factors, like seismic activity or intense or prolonged rainfall, happen in a region that is susceptible to landslides. Landslide susceptibility of a region is determined by the topography and the lithology, as well as soil type and land cover (Jaedicke et al., 2013). Steep slopes, the presence of water accumulation zones, as well as soils with an impermeable layer typically increase the landslide susceptibility (Corominas et al., 2014; Dai, Lee, \& Ngai, 2002).

In the East African highlands, landslides cause large-scale soil degradation and loss of assets, infrastructure and human life (Knapen et al., 2006; Mugagga et al. 2010; Ngecu et al. 2004). Yet the remoteness of the affected areas and the small size of single events lead to serious underreporting of landslides in these regions. This fact results in limited scientific attention and an underestimation of the impact of landslides on human livelihoods and development (Msilimba 2009; Jacobs et al. 2015).

The small scale and relatively diffuse character of most landslides makes the assessment of their impacts a challenging issue (Petley, 2012). In industrialized countries most studies evaluate the impact of landslides by estimating the (potential) costs related to direct damage of infrastructure or by estimating the foregone income for specific industries (e.g. Crovelli \& Coe, 2009; Klose et al. 2014; Petrucci \& Gullà, 2009; Vranken et al. 2013). In developing countries and especially in Sub-Saharan Africa (SSA), where landslides most frequently affect poor people in remote areas with limited infrastructure, such approaches do not grasp the extent of landslide impacts (Msilimba, 2009). Qualitative case studies suggest that landslides in East Africa significantly affect smallholder farmers' income through the loss of houses, crops and soil fertility (Kitutu et al. 2011; Msilimba, 2009; Mugagga et al., 2010). To our knowledge, no methodology currently exists to quantitatively assess the direct impact of landslides on household income in underdeveloped regions. Impact assessments are, however, necessary to understand how and to what extent landslides affect human livelihoods and the economic development in these regions. Moreover, developing an approach to estimate the impact of landslides in rural areas is a necessary step towards the implementation of cost-effective disaster risk reduction in such regions.

The objective of this paper is to propose a method to estimate the direct impact of landslides on household income in remote areas with limited infrastructure. We apply this methodology on a case study in the Rwenzori mountains, Western Uganda. We combine geographical data from fieldwork and digital elevation models (DEMs) with detailed information on natural hazards and socio-economic characteristics at household level. This unique combination of data sources illustrates how information on biophysical processes can be combined with detailed socio-economic data to advance the understanding of disaster impact. 
This study differs from other recent studies on the impact of natural hazards in several ways. First, it estimates the impact of landslides with an approach that is new for this idiosyncratic shock: instead of estimating the immediate damage of landslides to infrastructure, this study estimates the impact of landslides on household income. Secondly, both information on household livelihoods and on disasters is collected at household level, contrary to most studies which only investigated natural hazards at a more aggregate level (e.g. Arouri et al., 2015). Looking at one specific natural hazard which causes idiosyncratic, rather than covariate, shocks at household level allows to disentangle the direct impact from the indirect effects on household income (e.g. Cameron \& Shah, 2015). We make use of GIS to explicitly control for geographical factors that can influence landslide susceptibility as well as household income. Finally, this research is carried out in a remote region that is generally underresearched with regard to disasters (Jacobs et al. 2015).

\section{Materials and methods}

\subsection{Conceptual framework}

Rural household $(\mathrm{HH})$ income is determined by many factors and these are widely studied in agricultural economics (e.g. Deaton, 1997). It is acknowledged that income in rural developing regions is highly dependent on human, social and physical capital available to the household (Deaton, 1997). Human and social capital include education, experience, status and access to social networks. Physical capital includes the availability of cultivable land, climate and other productive assets. It has been stressed that many of the factors that determine income are intergenerational, being transferred from one generation to the other (Hulme \& Shepherd, 2003; Wolfe \& Behrman, 1984).

Natural hazards both directly and indirectly affect household income. The purpose of the current study was to isolate and estimate the direct impact of landslides on household income. To do this, it was necessary to control for potential indirect effects. A first type of indirect effects concerns off-site impacts. In contrast to direct impacts, off-site impacts refer to all consequences landslides may have outside the exact spot of their occurrence (Alimohammadlou et al. 2013). Landslides may, for example, decrease the access to markets by cutting off roads or they may cause floods and excessive sediment deposition by temporarily damming rivers (e.g. Claessens et al. 2007; De Haen \& Hemrich 2007; Meyer et al. 2013). While critical infrastructure is limited in our study area, the indirect effects of landslides can still potentially decrease the income of the households at an aggregated geographical level (e.g. at village level) and can be controlled for by including village fixed effects into the analysis.

A second indirect consequence of landslides is related to landslide risk. Regardless of the actual occurrence of a landslide, the mere exposure to its risk can affect income by influencing the behaviour of the household (Cameron \& Shah, 2015; Gloede et al. 2015). When attempting to estimate the direct impact of landslides on household income, it is therefore necessary to control for geographical variables that determine landslide susceptibility, which can be used as a proxy for exposure to landslide risk. This is even more relevant if one considers that poor households very often live in the most susceptible areas, thereby possibly exaggerating the measured impact of landslides (Wisner, 2001).

When directly affecting a household's house or plots, landslides often destroy crops and productive assets, essentially soil quality and livestock, and thereby cause a shock. We hypothesise that income from agriculture is reduced and, in case insufficient alternative income sources are found, also total income is affected. The extent to which income from agriculture is reduced depends on the size and type of the landslide, while the extent to which total income is affected also depends on the capacity of the household to find alternative income sources. This capacity, strongly related to coping capacity, depends on the access to human, social, physical and financial capital, as well as the livelihood 
strategies and services available in the region (Cutter et al., 2008; Rose, 2004; Thanapackiam et al. 2012; Wisner et al. 2003).

Most landslides are relatively small and local, causing idiosyncratic shocks which only affect a few plots at the same time (Glade, 2003). The household coping capacity for idiosyncratic shocks can be high if sufficient alternative livelihood strategies and/or adequate risk-sharing mechanisms are present and accessible for all within a community (Dercon, 2006; Sen, 2001). Finding a significant income shock due to landslides would suggest that improving the access to either income sources outside agriculture or local risk-sharing mechanisms could be a way to improve local resilience against landslide.

\subsection{Research area}

The research area is located within the Rwenzori mountains in Western Uganda $\left(0^{\circ} 2^{\prime} 37^{\prime \prime}-0^{\circ} 48^{\prime} 20^{\prime \prime} \mathrm{N}\right.$ and $29^{\circ} 46^{\prime} 20^{\prime \prime}-30^{\circ} 15^{\prime} 35^{\prime \prime} \mathrm{E}$ ). This tropical mountain range covers an area of approximately $3000 \mathrm{~km}^{2}$, spread over 31 sub-counties in four districts: Kabarole, Kasese, Bundibugyo and to a lesser extent Ntoroko (Figure 1). Two rainy seasons typically last from September to December and from March to May (Taylor et al. 2009). The subsoil is dominated by gneiss in Kabarole and Kasese and by rift alluvium and gneiss in Bundibugyo (GTK Consortium, 2012). The most important cash crop in Kabarole and Kasese is coffee, while Bundibugyo is dominated by cocoa production. Staple crops are manioc, jam, maize, beans, corn and vegetables, though many farmers also grow part of these crops for selling.

The most important ethnic group in the mountains is Bakonzo, but also people from the Babouissi, Bamba and Batoro are present. Bakonzo typically live in the higher regions and consequently on steeper slopes. Among Bakonzo, living on top of a hill is frequently considered as a status symbol.

During the two rainy seasons and following seismic activities, landslides frequently occur both high into the mountains and on the foot-slopes, close to the valleys. Despite a serious underreporting, landslides and flash floods in the Rwenzori are known to have caused at least 55 fatalities and rendered over 14,000 people homeless in the region over the last 50 years (Jacobs et al. 2015).

\subsection{Sampling procedure and data collection}

Seven sub-counties, typically ca $30 \mathrm{~km}^{2}$, with frequent landslides were selected for household sampling (Figure 1). To do this, workshops were conducted in three districts with members of the local government, non-government organizations (NGO) and peasant organisations during the first half of 2014 (Kervyn et al., n.d.). During these workshops participants were asked to indicate which subcounties were most affected by landslides by name or by location. Participants were also asked to describe the consequences of landslides and to discuss possible resilience strategies. After these workshops, several exploratory field visits were conducted in the whole region and finally seven subcounties highly affected by landslides were retained for household sampling (Figure 1).

In these sub-counties both affected and unaffected villages have been sampled. A village was identified as 'affected' if at least one household was affected by a landslide in the past 15 years. A household was defined as 'affected' if at least one landslide occurred on one of the plots owned or cultivated by the household. No distinction was made between landslides originating on the plots, thus removing soil from the plot, and landslides originating above the plots, therefore likely to deposit debris on the plots. The location of the homestead and the surrounding croplands have also been considered as a plot. Some summary information of the sample structure by district is given in Table 1.

A stratified two-stage random sample of 461 households in 47 villages, of which 10 in Kabarole, 15 in Kasese and 22 in Bundibugyo, were selected. This sample consisted of 80 unaffected households in 15 unaffected villages, and 201 unaffected and 180 affected households in 32 affected villages. On average $20 \%$ of the households in the affected villages in our sample have been affected by at least 
one landslide. Both affected households and affected villages were purposefully oversampled in order to obtain a sample with sufficient affected households for analysis. Due to the low landslide density in Kabarole, fewer villages have been sampled in this district. The high landslide density and heterogeneous topography, as well as the presence of three sub-counties severely affected by landslides, explains why more villages have been sampled in Bundibugyo.

Table 1: Number of affected and unaffected households (HHs) in total and by district for the sampled villages. Standard deviations are between brackets.

\begin{tabular}{|l|c|ccc|}
\hline & Total & Kabarole & Kasese & Bundibugyo \\
\hline Average number of HHs per village & 139 & 177 & 164 & 106 \\
& $(69)$ & $(52)$ & $(75)$ & $(54)$ \\
\hline Average number of affected HHs in affected villages & 28 & 17 & 25 & 34 \\
& $(23)$ & $(10)$ & $(10)$ & $(30)$ \\
\hline Total number of affected HHs sampled & 180 & 33 & 52 & 95 \\
\hline Total number of unaffected HHs sampled & 281 & 60 & 97 & 124 \\
\hline
\end{tabular}

Source: Data obtained from personal interviews with local chairmen.

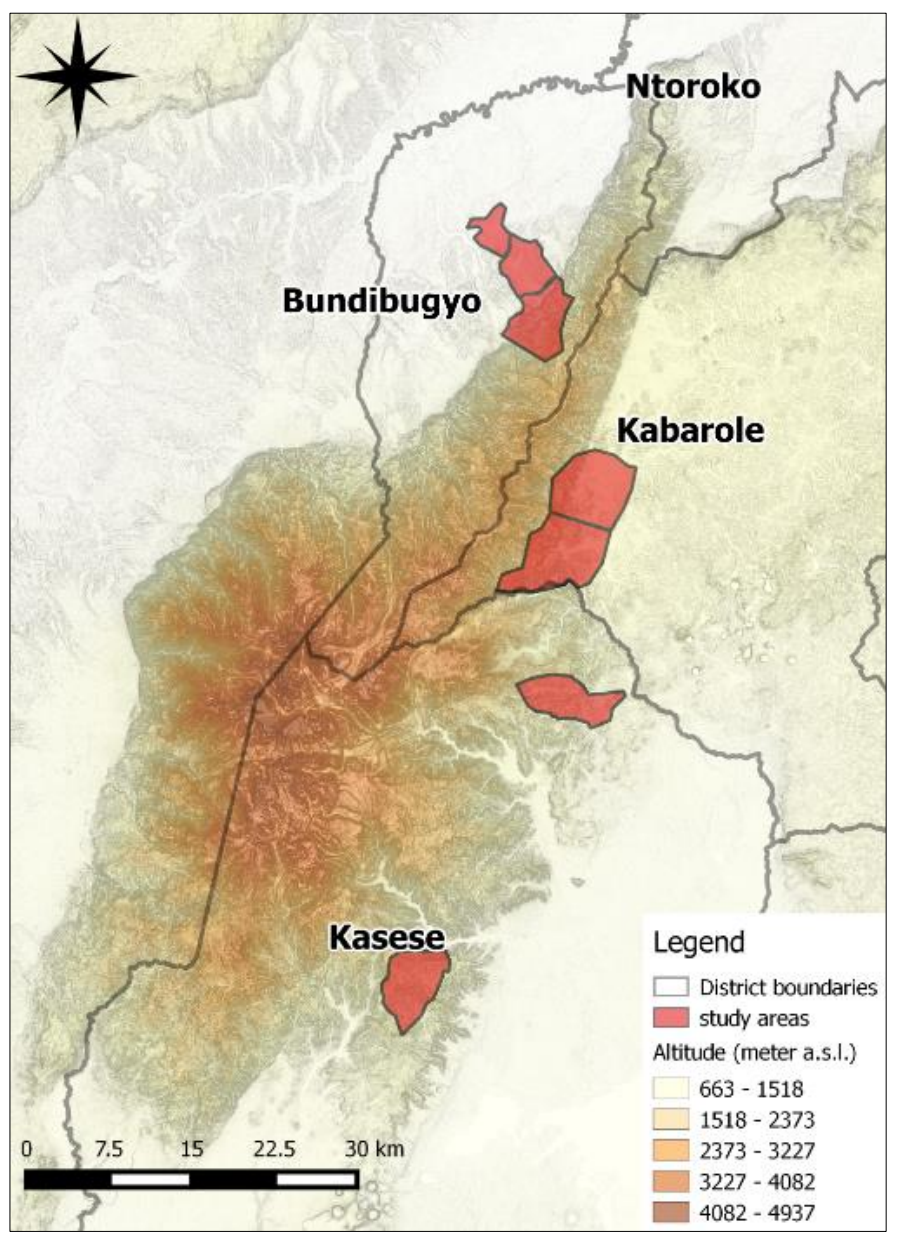

Figure 1: Overview of the study area. Darker areas have a steeper slope

Within every village, households were randomly picked from a list with all household heads in the village. In order to oversample affected households, each time a name was picked, the local chairman was asked to indicate whether that household had been affected by landslides or not. Whenever possible, an equal number of 6 affected and 6 unaffected households was selected in affected villages, while 6 unaffected households were selected in unaffected villages. As local chairmen were not always fully aware of all landslides in their village and sometimes confused landslides with gully erosion, small imbalances exist between affected and unaffected households in some villages. 
Interviews with the households were conducted in the beginning of 2015 and lasted between three to four hours, including breaks. The questionnaires consisted of 13 sections covering questions on household demographics, land management and ownership, living conditions, agricultural production and marketing, experiences with landslides and other disasters, various income sources and social capital. Household income data were obtained following the methods recommended by the World Bank (2000). Total income includes income from agricultural production, both for selling and own consumption, income from wage labour and off-farm employment, as well as non-labour income including gifts, transfers and monetary and non-monetary support. GPS coordinates were taken in front of the house of each household, as well as on the corners of the plots owned or cultivated by the household. This made it possible to include geographical variables at household level and to calculate the exact area of land cultivated by each household.

During data cleaning nine households were dropped because of too much missing information, while two households were dropped because they were severe outliers owning a very large area of land and having a very high income, therefore not considered representative for the study area. While these two households did not affect the results of the econometric analysis, their very high income seriously increased standard deviations in the descriptive statistics.

\subsection{Retrieval of geographic information}

Geographic information was used as a proxy for landslide susceptibility in order to control for the impact of landslide susceptibility on household income. Landslide susceptibility is expected to be correlated with both the occurrence of landslides and household income. This has been explained in the conceptual framework and will be further elaborated in the empirical approach. The main landslide-controlling factors in the Rwenzori region are slope steepness and lithology, while slope undercutting by water flows and streams is one of the preparatory factors (Jacobs, et al. 2015). Additionally, soil type, which is only partially determined by lithology, has also been identified as a controlling factor for landslide occurrence. Yet, no data on soil type are available for the Rwenzori region (Jacobs, et al. 2015).

Slope steepness and flow accumulation were calculated with a Shuttle Radar Topography Mission Digital Elevation Model with a resolution of 30 by 30 meters (SRTM 30m DEM from USGS, 2014). The flow accumulation tool in ArcGIS calculates a scale-dependent value of flow accumulation in each cell of a raster. Therefore it first estimates the flow direction in each cell, based on the direction of the slope in these cells. Subsequently it calculates a relative value for flow accumulation by counting the number of cells 'flowing' into each cell from a higher altitude (ESRI, 2015). Data on the lithology in the Rwenzori was retrieved from the geological map of Uganda (GTK Consortium, 2012).

A way to obtain a measure for slope steepness, lithology and flow accumulation at household level could have been to assess these factors around the house and all the plots of each household. Yet, as plots were generally within 'walking distance' (less than $5 \mathrm{~km}$ ) from the house, with a decreasing plot density as the distance from the house increased, the location of the plots was highly correlated with the location of the house. In our sample, average walking time between the house and plots was 28 min and over $85 \%$ of the households had an average walking time to their plots equal to or less than one hour. To obtain single values of slope steepness, flow accumulation and lithology for each household, we calculated the weighted sum of pixel values in a buffer of five $\mathrm{km}$ around each house. A weight was attributed to each cell by dividing the value of each pixel by the squared distance from the house.

All calculations were performed in ArcGIS 10.3 (ESRI, 2015). The weighed focal statistics tool in ArcGIS was used to calculate the weighed values for the buffer around the houses (ESRI, 2015). 


\subsection{Empirical approach}

An ordinary least squares (OLS) regression model was used to estimate the impact of the occurrence of a landslide on the income of the households in our sample (equation 1).

$$
Y_{i j}=\alpha+\beta L S_{i j}+\gamma \text { Susceptibility }_{i j}+\delta X_{i j}+\mu \text { Village } F E_{j}+\varepsilon_{i j}
$$

In this model $Y_{i j}$ is a measure for household welfare, i.e. the logarithm of per capita income. The logarithm of income was taken to normalize the data which are right-tailed. The first parameter, $\alpha$, is the constant, sometimes called the intercept, of the model. $L S_{i j}$ is a dummy which equals 1 if the household was affected by a landslide in the past 15 years. Susceptibility $y_{i j}$ represents the set of variables which control for landslide susceptibility, i.e. the calculated values of slope steepness, lithology and flow accumulation. Controlling for these factors likely solves issues related to potential omitted variable bias. $X_{i j}$ represents a vector of covariates, while Village $F E_{j}$ and $\varepsilon_{i j}$ are village fixed effects and the error term.

The covariates considered in our model include demographic variables and variables for human, social and productive capital. The demographic variables include household size, as well as gender, age and education of the household head, which are proxies for human capital. A dummy for whether the household head is from the main ethnicity in the region, i.e. Bakonzo, was included as a proxy for social capital. As living on top of a hill is considered to be a status symbol in the region, the altitude of the house (m.a.s.l.) was also added as a proxy for social capital within the village. To control for intergenerational factors, the number of brothers of the household head and the education level of the parents of the household head were included. These intergenerational factors often determine what land is available to a household head and thus where a household head will construct its house. The variables for productive capital are total land area and number of plots, percentage of land under cash crops (coffee or cocoa) and a dummy for whether at least one household member has an income source from self-employed activities or from wage labour.

Equation 1 does not fully capture what happens when a household is affected, because landslides do not always occur on the totality of a household's land. A landslide can affect one out of several plots, or even only a part of a plot. Therefore in equation 2 the dummy $L S_{i j}$ was replaced by the percentage of the total cultivated land that was affected by a landslide, $\operatorname{LSP}_{\operatorname{erc}} \mathrm{i}_{j}$.

$$
Y_{i j}=\alpha+\beta \operatorname{LSPerc}_{i j}+\gamma \text { Susceptibility }_{i j}+\delta X_{i j}+\mu \text { Village } F E_{j}+\varepsilon_{i j}
$$

In this equation the coefficient $\beta$ estimates how much percentage the income of a household was changed by each additional percentage of the total area that was hit by a landslide.

After the initial welfare shock, it is likely that the impact of a landslide fades away over time. It is therefore interesting to estimate the impact of landslides that occurred during different periods. Equation 3 estimates the impact of landslides that happened less than one year ago, between one and two years ago, two or three years ago and landslides that happened longer time ago.

$$
\begin{array}{r}
Y_{i j}=\alpha+\beta_{t 1} \operatorname{LPPerc}(t 1)_{i j}+\beta_{t 2} \operatorname{LSPerc}(t 2)_{i j}+\beta_{t 3} \operatorname{LSPerc}(t 3)_{i j}+\beta_{t 4} L \operatorname{SPerc}(t 4)_{i j}+ \\
\gamma \operatorname{Susceptibility}_{i j}+\delta X_{i j}+\mu \operatorname{Village} F E_{j}+\varepsilon_{i j}
\end{array}
$$

To explain the findings of these OLS regressions on household income, equation 3 was also used for a probit estimation on potential coping strategies adopted by affected households after a landslide has occurred. The coping strategies that were considered are: (1) having a household member with a job outside own agriculture, or (2) having received gifts or transfers in the last year. 
As a robustness check, a treatment-effects estimation with augmented inverse probability weighting has been displayed in the appendix. In this estimation households were considered as 'treated' if they had been affected by a landslide. After controlling for factors that could determine variations in the likelihood to be treated, the average impact of landslides (Average Treatment Effect) was estimated as the difference between affected and unaffected households. The augmented inverse probability weighting estimation was used because this estimation allows a similar specification as in the OLS estimations, while being robust to misspecifications in either the estimation of the likelihood to be treated or the estimation of the impact of the treatment. For more information on this estimation method, please read Glynn \& Quinn (2010) or Stata Press (2013). All analyses have been performed with the Stata 14 software (StataCorp, 2015).

\section{Results}

\subsection{Descriptive statistics}

The households in the sample are very poor, with an average income of 2,911 Ugandan Shilling (Ush) per day per adult equivalent (Table 2). This is the equivalent of 2.83 USD per adult per day (purchasing power parity in 2010-2014 from "WorldBank" 2015). Income from agriculture represents $85 \%$ of the total income. Incomes in the sample are lower than the average in the districts under study, as average consumption per adult equivalent is around 4,300 Ush per day (converted from UNDP 2014). This is understandable, as our sample targets households in the mountains, far from local towns and exposed to landslides. Approximately $40 \%$ of the households in our sample have been affected by a landslide in the past 15 years (Table 2). No significant difference in income exists between households affected by landslides and unaffected households. This is surprising, as $64 \%$ of the affected households mention that they faced hunger after the landslide, while $18.5 \%$ say at least one of the children of the household temporarily or permanently missed school due to the landslide.

According to the multidimensional poverty index (MPI) of Alkire et al. (2011), most households in our sample are multi-dimensionally poor, with $90 \%$ below the poverty line. According to this index, households are defined as poor if they obtain a deprivation score of at least 33 out of 100, which implies they have a serious lack of access to education, health and basic living standards (Alkire et al., 2011). Again, no difference exists between affected and unaffected households regarding the MPI (Table 2). Yet, households affected by a landslide seem to have a significantly less educated household head.

On average, $38 \%$ of the households has borrowed money in the 12 months before the interview. This can be either through a bank, a microcredit institution or an individual lender. Meanwhile, $49 \%$ of the households has a mobile money account, used to transfer money across phones, or has an account at a bank or a microcredit institute. No significant differences exist between affected and unaffected households.

As can be seen in Table 2, the households in our sample own on average 0.8 ha spread over two plots. Households that have been affected by a landslide have significantly more land, spread over significantly more plots than unaffected households. This suggests that there is a selection bias in our sample. The sample was not stratified on the area of land owned by the households. In a village where most of the land is susceptible to landslides, households owning more plots are more likely to be affected by a landslide just because they own a larger area. This selection bias could explain why no lower income is found among affected households in Table 2.

Approximately $50 \%$ of the land is planted with coffee or cocoa, whereby coffee is often intercropped with other crops, i.e. banana, beans, cassava and jams. Respectively $22 \%$ and $35 \%$ of the households 
have a member involved in wage labour or self-employed activities outside agriculture. In our sample, most wage labour consists of performing part-time work on the fields of other farmers, while selfemployed jobs embrace a variety of activities like owning shops, trading cash crops or driving motorbikes for transportation. In total, approximately $50 \%$ of the households has at least one member with a job different from agriculture on its own plots. Among these households, the average household income from these jobs is 754 Ush ( 0.74 USD) per adult equivalent per day. Approximately $49 \%$ of the households received gifts or transfers in the previous 12 months, amounting for an average of 184 Ush ( 0.18 USD) per adult equivalent per day. In the overall sample, no significant differences exist in crop type, activities outside agriculture or transfers between affected and unaffected households.

A significant difference between affected and unaffected households exists for the lithology and for the calculated flow accumulation. This suggests that these variables are indeed correlated with landslide susceptibility and should therefore be controlled for. Due to a high correlation between the village fixed effects and the continuous estimations of lithology in the buffers around the houses, a dummy variable was used for lithology, indicating the dominant lithology in the buffer around each house in the sample. Altitude and calculated value of slope are not significantly different in the overall sample.

Table 2: Summary statistics of main variables (averages with standard deviations in parentheses) for the whole sample and for unaffected and affected households (HHs). Only variables used in the subsequent regressions were given an acronym. Variable units are in square brackets (if applicable). Standard deviation in parentheses. N/A stands for 'Not Applicable'. The last column represents the results of $t$-tests between unaffected and affected households $* p<0.10, * * p<0.05, * * *$ $\mathrm{p}<0.01$

\begin{tabular}{|c|c|c|c|c|c|}
\hline Explanation & $\begin{array}{l}\text { Variable } \\
\text { acronyms }\end{array}$ & Sample & $\begin{array}{c}\text { Unaffected } \\
\text { HHs }\end{array}$ & $\begin{array}{l}\text { Affected } \\
\text { HHs }\end{array}$ & $\begin{array}{l}\text { Diff. (unaff. } \\
\text { - aff.) }\end{array}$ \\
\hline \multicolumn{6}{|l|}{ Welfare indicators } \\
\hline Income [Ush/day/adult-equivalent] & & $\begin{array}{c}2912 \\
(2710)\end{array}$ & $\begin{array}{c}3012 \\
(2796)\end{array}$ & $\begin{array}{c}2752 \\
(2566)\end{array}$ & \\
\hline Income from agriculture [\% of total income] & & $\begin{array}{c}86 \\
(23)\end{array}$ & $\begin{array}{c}84 \\
(24)\end{array}$ & $\begin{array}{l}88 \\
(21)\end{array}$ & \\
\hline \multicolumn{6}{|l|}{ Experience with landslides } \\
\hline $\mathrm{HH}$ affected by landslide [\%] & LS & $\begin{array}{c}39 \\
(49)\end{array}$ & $\begin{array}{c}0 \\
0\end{array}$ & $\begin{array}{l}100 \\
(0)\end{array}$ & N/A \\
\hline Time since most recent landslide [years] & & N/A & N/A & $\begin{array}{c}1.60 \\
(1.79)\end{array}$ & N/A \\
\hline $\begin{array}{l}\text { HHs who's house was damaged by most } \\
\text { recent landslide [\%] }\end{array}$ & & $\begin{array}{c}8 \\
(27)\end{array}$ & $\begin{array}{c}0 \\
(0)\end{array}$ & $\begin{array}{c}21 \\
(41)\end{array}$ & N/A \\
\hline \multicolumn{6}{|l|}{ Human and social capital } \\
\hline Adult equivalents (OECD) [\#] & $\mathrm{AdEq}$ & $\begin{array}{c}3 \\
(1)\end{array}$ & $\begin{array}{c}3 \\
(1)\end{array}$ & $\begin{array}{c}3 \\
(1)\end{array}$ & \\
\hline Age of HH head [years] & AgeHHH & $\begin{array}{c}45 \\
(16)\end{array}$ & $\begin{array}{c}44 \\
(16)\end{array}$ & $\begin{array}{c}46 \\
(16)\end{array}$ & $*$ \\
\hline Formal education $\mathrm{HH}$ head [years] & EducHHH & $\begin{array}{c}6 \\
(4)\end{array}$ & $\begin{array}{c}6 \\
(4)\end{array}$ & $\begin{array}{c}5 \\
(3)\end{array}$ & $* *$ \\
\hline $\mathrm{HH}$ head is female [\%] & Female & $\begin{array}{c}9 \\
(29)\end{array}$ & $\begin{array}{c}9 \\
(29)\end{array}$ & $\begin{array}{c}9 \\
(29)\end{array}$ & \\
\hline Ethnicity $\mathrm{HH}$ head is Bakonzo [\%] & Ethnicity & $\begin{array}{c}60 \\
(49)\end{array}$ & $\begin{array}{c}63 \\
(48)\end{array}$ & $\begin{array}{c}56 \\
(50)\end{array}$ & \\
\hline Formal education parents of $\mathrm{HH}$ head [years] & EducParents & $\begin{array}{c}2 \\
(3)\end{array}$ & $\begin{array}{c}2 \\
(3)\end{array}$ & $\begin{array}{c}2 \\
(3)\end{array}$ & \\
\hline Original number of brothers of $\mathrm{HH}$ head [\#] & BrothersHHH & $\begin{array}{c}4 \\
(2)\end{array}$ & $\begin{array}{c}4 \\
(2)\end{array}$ & $\begin{array}{c}3 \\
(2)\end{array}$ & \\
\hline \multicolumn{6}{|l|}{ Productive capital } \\
\hline Land area available to household [hectares] & TotArea & $\begin{array}{c}0.81 \\
(0.71)\end{array}$ & $\begin{array}{c}0.74 \\
(0.67)\end{array}$ & $\begin{array}{c}0.92 \\
(0.76)\end{array}$ & $* * *$ \\
\hline $\begin{array}{l}\text { Number of different plots available to the } \mathrm{HH} \\
{[\#]}\end{array}$ & TotPlots & $\begin{array}{c}1.95 \\
(1.03)\end{array}$ & $\begin{array}{l}1.82 \\
(0.94)\end{array}$ & $\begin{array}{c}2.16 \\
(1.12)\end{array}$ & $* * *$ \\
\hline Land with coffee or cocoa (cashcrops) [\% of & PercCash & 47 & 49 & 46 & \\
\hline
\end{tabular}




\begin{tabular}{|c|c|c|c|c|c|}
\hline $\begin{array}{l}\text { total area] } \\
\text { HHs where at least one member is self- } \\
\text { employed or has a wage [\%] } \\
\text { HHs with an account (mobile money, bank or } \\
\text { microcredit institute) [\%] }\end{array}$ & Job & $\begin{array}{c}(32) \\
50 \\
(50) \\
49 \\
(50)\end{array}$ & $\begin{array}{c}(33) \\
53 \\
(50) \\
49 \\
(50)\end{array}$ & $\begin{array}{c}(31) \\
45 \\
(50) \\
48 \\
(50)\end{array}$ & \\
\hline \multicolumn{6}{|l|}{ Geographical information } \\
\hline Altitude of house [m.a.s.I.] & Altitude & $\begin{array}{l}1369 \\
(404)\end{array}$ & $\begin{array}{l}1390 \\
(399)\end{array}$ & $\begin{array}{l}1336 \\
(411)\end{array}$ & \\
\hline $\begin{array}{l}\text { Slope / squared distance in buffer of } 5 \mathrm{~km} \\
\text { around house }\left[\mathrm{m}^{-2}\right]\end{array}$ & Buf_Slope & $\begin{array}{c}4.39 \\
(1.69)\end{array}$ & $\begin{array}{c}4.35 \\
(1.67)\end{array}$ & $\begin{array}{c}4.47 \\
(1.72)\end{array}$ & \\
\hline $\begin{array}{l}\text { Variable for water accumulation / squared } \\
\text { distance in buffer }\left[\mathrm{m}^{-2}\right]\end{array}$ & Buf_Water & $\begin{array}{c}90.81 \\
(30.52)\end{array}$ & $\begin{array}{c}88.59 \\
(29.72)\end{array}$ & $\begin{array}{c}94.34 \\
(31.51)\end{array}$ & * \\
\hline $\begin{array}{l}\text { Gneiss is dominant lithology in weighted } \\
\text { buffer around house [\%] }\end{array}$ & Gneiss & $\begin{array}{c}62 \\
(49)\end{array}$ & $\begin{array}{c}64 \\
(48)\end{array}$ & $\begin{array}{c}57 \\
(50)\end{array}$ & \\
\hline $\begin{array}{l}\text { Rift alluvium is dominant lithology in } \\
\text { weighted buffer around house [\%] }\end{array}$ & Rift & $\begin{array}{c}33 \\
(47)\end{array}$ & $\begin{array}{c}29 \\
(46)\end{array}$ & $\begin{array}{c}39 \\
(49)\end{array}$ & $* *$ \\
\hline $\begin{array}{l}\text { Mica is dominant lithology in weighted buffer } \\
\text { around house [\%] }\end{array}$ & Mica & $\begin{array}{c}5 \\
(22)\end{array}$ & $\begin{array}{c}6 \\
(24)\end{array}$ & $\begin{array}{c}3 \\
(18)\end{array}$ & \\
\hline \# Observations & & 450 & 276 & 174 & \\
\hline
\end{tabular}

The summary statistics in Table 2 compare affected and unaffected households and show that the most significant difference lies in the average total area and number of plots owned by the households. Affected households have on average significantly more available land (in ha) and more plots. Yet, not all affected households own a large area of cropland or more than one plot. In Table 3 differences in income and land area between affected and unaffected households are represented and grouped by the number of plots available to the households. Among households with only one plot, there is no difference in total cultivated area between affected and unaffected households. Meanwhile, a significant difference in income between affected and unaffected households with only one plot is found. Among households with more than one plot, there is a significant difference in total cultivated area between affected and unaffected households, while no difference in income is found. Interestingly, among households with only one plot a significantly larger percentage of the total land area is subjected to landslides than among households with more than one plot.

Table 3: Summary statistics on income and land area among affected and unaffected households (HHs), grouped by number of plots cultivated by the household (one or more plots). Standard deviation in parentheses. To test for significant differences t-test have been performed between unaffected and affected households and between households with one plot and households with more plots $* p<0.10, * * p<0.05, * * * p<0.01$

\begin{tabular}{|c|c|c|c|c|c|c|c|c|}
\hline $\begin{array}{c}\# \\
\text { Plots }\end{array}$ & $\begin{array}{c}\text { Income } \\
\text { unaffected HHs } \\
\text { [Ush/day/adult- } \\
\text { equivalent] }\end{array}$ & & $\begin{array}{c}\text { Income affected } \\
\text { HHs } \\
\text { [Ush/day/adult- } \\
\text { equivalent] }\end{array}$ & $\begin{array}{c}\text { Total area } \\
\text { available to } \\
\text { unaffected HHs } \\
\text { [hectares] }\end{array}$ & & $\begin{array}{c}\text { Total area } \\
\text { available to } \\
\text { affected HHs } \\
\text { [hectares] }\end{array}$ & $\begin{array}{c}\% \text { of land } \\
\text { subjected to } \\
\text { landslide among } \\
\text { affected } \mathrm{HHs}\end{array}$ & $\begin{array}{c}\# \\
\mathrm{HHs}\end{array}$ \\
\hline 1 & $\begin{array}{c}2441 \\
(2139)\end{array}$ & $*$ & $\begin{array}{c}1855 \\
(1612)\end{array}$ & $\begin{array}{c}0.60 \\
(0.59)\end{array}$ & & $\begin{array}{c}0.74 \\
(0.87)\end{array}$ & $\begin{array}{c}43 \\
(20)\end{array}$ & 179 \\
\hline & $* * *$ & & $* * *$ & $* * *$ & & $* *$ & $* * *$ & \\
\hline$>1$ & $\begin{array}{c}3465 \\
(3158)\end{array}$ & & $\begin{array}{c}3188 \\
(2825)\end{array}$ & $\begin{array}{c}0.84 \\
(0.71)\end{array}$ & $*$ & $\begin{array}{c}1.00 \\
(0.69)\end{array}$ & $\begin{array}{c}22 \\
(15)\end{array}$ & 271 \\
\hline
\end{tabular}

Table 2 and Table 3 give only a partial picture of the reality due to several reasons. First, not all landslides considered in this research occurred at the same time. Therefore, some households might have been affected a longer time ago than others. Secondly, many households have been affected by a landslide several times, for example during consecutive rain seasons. This can be due to a reactivation of a landslide or due to another landslide affecting the same or a different plot. Finally, the extent to which a landslide has stricken a household's land varies greatly. A landslide can affect $100 \%$ of a plot cultivated by a household that has only one plot, or it could damage only $25 \%$ of a small plot owned by a household that is cultivating many plots. 
In total 273 landslides have directly affected 174 households in our sample (Table 4). One third of the households affected by a landslide state that a landslide occurred only once on their plots, while the majority has been affected two times. More than $40 \%$ of the affected households in our sample were affected by a landslide less than 1 year ago, while more than $80 \%$ was affected less than 4 years ago. This strong bias towards more recent landslides is attributed to our sample design, whereby the village chairmen were asked whether a household was affected by a landslide or not. As village chairmen are not personally affected by the disaster, they are likely to forget landslides that occurred a longer time ago. On average the landslides in our sample affected $27.4 \%$ of the land available to the farmers. More than half of the landslides has stricken $25 \%$ or less of the land available to the affected households.

Table 4: Overview of number of households (HHs) affected by a landslide (LS) and the average percentage of cultivated area affected per household in column 2 and 4 respectively, grouped by year since the landslide. Column 3 illustrates that most households in our sample have been recently affected by a landslide. Standard deviation in parentheses (if applicable)

\begin{tabular}{|l|ccc|}
\hline Year of landslide occurrence & $\begin{array}{c}\text { \# HHs affected by a } \\
\text { LS }\end{array}$ & $\begin{array}{c}\text { \# HHs for whom } \\
\text { the LS in the given } \\
\text { year was the most } \\
\text { recent one }\end{array}$ & $\begin{array}{c}\text { Average \% of area } \\
\text { affected by the LS }\end{array}$ \\
\hline - 1 year ago (2014) & \multicolumn{3}{|c|}{$28(18)$} \\
$1-2$ years ago (2013) & 61 & 61 & $24(19)$ \\
2 - 3 years ago (2012) & 54 & 49 & $30(23)$ \\
$3-4$ years ago (2011) & 15 & 27 & $26(19)$ \\
$4-5$ years ago (2010) & 22 & 6 & $29(17)$ \\
$5-6$ years ago (2009) & 12 & 14 & $24(14)$ \\
$>6$ years ago (2008 or earlier) & 43 & 6 & $28(17)$ \\
\hline Total & 273 & 11 & \\
\hline
\end{tabular}

In order to take into consideration the time since landslides, it is worth looking deeper into the significant differences between affected and unaffected households with only one plot, as suggested by the income differences found in Table 3. Despite the limited number of observations, Table 5 shows that, among households owning one plot, those affected by a landslide less than one year ago, as well as those affected between one and two years ago have a significantly lower income than unaffected households. This trend is not found for households owning more than one plot.

Table 5: Differences among affected and unaffected households (HHs) with only 1 plot for the most important variables, split by year of landslide (LS) occurrence. Standard deviation in parentheses. To test for significant differences t-test have been performed between unaffected households and respective columns $* p<0.10, * * p<0.05, * * * p<0.01$

\begin{tabular}{|c|c|c|c|c|c|}
\hline & $\begin{array}{c}\text { Unaffected } \\
\mathrm{HHs}\end{array}$ & $\begin{array}{c}\text { HHs affected by } \\
\text { LS } 0-1 \text { year } \\
\text { ago }\end{array}$ & $\begin{array}{c}\text { HHs affected by } \\
\text { LS } 1-2 \text { years } \\
\text { ago }\end{array}$ & $\begin{array}{c}\text { HHs affected by } \\
\text { LS } 2-4 \text { years } \\
\text { ago }\end{array}$ & $\begin{array}{c}\text { HHs affected } \\
\text { by } L S>4 \text { years } \\
\text { ago }\end{array}$ \\
\hline $\begin{array}{l}\text { Income [Ush/day/adult- } \\
\text { equivalent] }\end{array}$ & $\begin{array}{c}2441 \\
(2139)\end{array}$ & $\begin{array}{c}1585 \\
(1263)^{*}\end{array}$ & $\begin{array}{c}1460 \\
(822)^{*}\end{array}$ & $\begin{array}{c}1549 \\
(1524)\end{array}$ & $\begin{array}{c}2254 \\
(2238)\end{array}$ \\
\hline $\begin{array}{l}\text { Income from agriculture } \\
\text { [Ush/day/adult-equivalent] }\end{array}$ & $\begin{array}{c}2034 \\
(1999) \\
\end{array}$ & $\begin{array}{c}1371 \\
(1233) \\
\end{array}$ & $\begin{array}{c}1094 \\
(722)^{*}\end{array}$ & $\begin{array}{c}1263 \\
(1452)\end{array}$ & $\begin{array}{c}1845 \\
(1864) \\
\end{array}$ \\
\hline $\begin{array}{l}\text { Land area available to } \mathrm{HH} \\
\text { [hectares] }\end{array}$ & $\begin{array}{c}0.60 \\
(0.59)\end{array}$ & $\begin{array}{c}0.78 \\
(0.86)\end{array}$ & $\begin{array}{c}0.43 \\
(0.21)\end{array}$ & $\begin{array}{c}0.69 \\
(0.57)\end{array}$ & $\begin{array}{c}1.11 \\
(1.24)^{* * *}\end{array}$ \\
\hline $\begin{array}{l}\% \text { of land area affected by } \\
\text { landslide }\end{array}$ & $\begin{array}{c}0 \\
(0)\end{array}$ & $\begin{array}{c}40 \\
(19)\end{array}$ & $\begin{array}{c}40 \\
(21)\end{array}$ & $\begin{array}{c}50 \\
(27)\end{array}$ & $\begin{array}{c}38 \\
(17)\end{array}$ \\
\hline $\begin{array}{l}\text { HHs where at least one } \\
\text { member has a wage [\%] }\end{array}$ & $\begin{array}{c}23 \\
(42)\end{array}$ & $\begin{array}{c}38 \\
(50)\end{array}$ & $\begin{array}{c}28 \\
(46)\end{array}$ & $\begin{array}{c}13 \\
(34)\end{array}$ & $\begin{array}{c}10 \\
(30)\end{array}$ \\
\hline $\begin{array}{l}\text { HHs where at least one } \\
\text { member is self-employed [\%] }\end{array}$ & $\begin{array}{c}29 \\
(45)\end{array}$ & $\begin{array}{c}14 \\
(36)\end{array}$ & $\begin{array}{c}39 \\
(50)\end{array}$ & $\begin{array}{c}19 \\
(40)\end{array}$ & $\begin{array}{c}19 \\
(40) \\
\end{array}$ \\
\hline \# households & 122 & 21 & 18 & 16 & 21 \\
\hline
\end{tabular}




\subsection{The impact of landslides on household income}

The results of the village fixed effects regressions on the log of household income from agriculture (Ush/adult equivalent/day) are given in equations 1-3 of Table 6, while those on the log of total household income (Ush/adult equivalent/day) are given in equations 4-6. Except for some geographical variables as well as for EducHHH and Job, which only have a significant impact in regressions 4-6, all the covariates have a significant effect in regression 1 to 6 . Reduced-form regressions, without most covariates, give very similar results and are presented in the Appendix (Table A1).

The first equation in Table 6 gives the estimation of landslide impact on income from agriculture with a simple dummy which equals one if the household was affected by a landslide in the past 15 years. This measurement does not take into account the fact that some households might have been affected only to a very little extent or a long time ago. Yet, this equation nevertheless indicates that households that were affected by a landslide have on average $18 \%$ less income from agriculture. The same analysis on the total income (equation 4) does not give significant results. Similarly, the treatment effects estimation, displayed in the appendix, finds that landslides reduce income from agriculture by $16 \%$, while no significant impact is found on total income.

The second equation in Table 6 estimates that every additional percentage of land affected by the most recent landslide decreases the income from agriculture by $0.74 \%$, while the fifth equation shows that every additional percentage reduces the total income by $0.56 \%$. An average landslide in our sample has affected $27.4 \%$ of the land of the affected households. The estimations in equations two and four therefore suggest that households that have been affected by an average landslide have on average respectively $20 \%$ less income from agriculture and $15 \%$ less total income than households that have never been affected. These results do not take into account time since the landslide event, although one must keep in mind that most affected households in our sample have been affected less than 2 years ago.

The third and the sixth equation in Table 6 disentangle the effect of a landslide by time since the landslide. We find a negative effect of landslides on income from agriculture for landslides that occurred less than three years ago. A negative and significant effect on total household income is found for landslides that occurred less than one year ago or between two and four years ago. Landslides that happened more than four years ago seem to have no impact on current income.

The results displayed in Table 3 suggest that households which have only one plot are more severely affected by landslides than households that have more plots. We have tested this hypothesis by including an interaction term between $L S$ and TotPlots but this did not yield any significant result and is therefore not displayed here. It is nevertheless clear from the equations in Table 6 that the impact of landslides is highly dependent on the percentage of the land affected by the landslide. On average, households with more land are therefore likely to be less severely affected by average landslides than households which have less land.

Table 6: Results of Ordinary Least Square (OLS) regressions with village fixed effects (FE) on income per adult equivalent per day from agriculture (1-3) or total income per adult equivalent per day (4-6). t statistics in parentheses. $* p<0.10$, ** $\mathrm{p}<0.05, * * * \mathrm{p}<0.01$

\begin{tabular}{|l|cccccc|}
\hline Equation number & $(1)$ & $(2)$ & $(3)$ & $(4)$ & $(5)$ & $(6)$ \\
\hline Dependent variable & $\begin{array}{l}\text { Log(Income } \\
\text { agriculture) }\end{array}$ & $\begin{array}{l}\text { Log(Income } \\
\text { agriculture) }\end{array}$ & $\begin{array}{l}\text { Log(Income } \\
\text { agriculture) }\end{array}$ & $\log ($ Income) & Log(Income) & Log(Income) \\
\hline Experience with landslides & $-0.183^{* *}$ & & -0.127 & \\
\hline LS & $(-2.00)$ & & $(-1.44)$ & \\
\hline \% of land affected & & $-0.00735^{* * *}$ & & $-0.00561^{* *}$ \\
\hline
\end{tabular}




\begin{tabular}{|c|c|c|c|c|c|c|}
\hline by most recent LS & \multicolumn{3}{|c|}{$(-3.09)$} & \multicolumn{3}{|c|}{$(-2.33)$} \\
\hline $\begin{array}{l}\% \text { of land affected } \\
\text { by LS } 0-1 \text { year ago }\end{array}$ & & & $\begin{array}{c}-0.00588^{*} \\
(-1.71) \\
\end{array}$ & & & $\begin{array}{c}-0.00571^{*} \\
(-1.84)\end{array}$ \\
\hline $\begin{array}{l}\% \text { of land affected } \\
\text { by LS } 1-2 \text { years } \\
\text { ago }\end{array}$ & & & $\begin{array}{c}-0.00577^{*} \\
(-1.71)\end{array}$ & & & $\begin{array}{c}-0.00344 \\
(-1.01)\end{array}$ \\
\hline $\begin{array}{l}\% \text { of land affected } \\
\text { by LS } 2-4 \text { years } \\
\text { ago }\end{array}$ & & & $\begin{array}{c}-0.00612 \\
(-1.53)\end{array}$ & & & $\begin{array}{c}-0.00645^{*} \\
(-1.70)\end{array}$ \\
\hline $\begin{array}{l}\% \text { of land affected } \\
\text { by LS }>4 \text { years ago }\end{array}$ & & & $\begin{array}{l}0.0734 \\
(0.20) \\
\end{array}$ & & & $\begin{array}{l}0.104 \\
(0.29) \\
\end{array}$ \\
\hline \multicolumn{7}{|c|}{ Control variables on productive capital } \\
\hline TotArea [ha] & $\begin{array}{c}0.231^{* * *} \\
(2.91)\end{array}$ & $\begin{array}{c}0.227^{* * *} \\
(2.88)\end{array}$ & $\begin{array}{c}0.215^{* * *} \\
(2.67)\end{array}$ & $\begin{array}{c}0.184^{* * *} \\
(2.78)\end{array}$ & $\begin{array}{c}0.181^{* * *} \\
(2.75)\end{array}$ & $\begin{array}{c}0.171^{* *} \\
(2.55)\end{array}$ \\
\hline TotPlots [\#] & $\begin{array}{c}0.272^{* * *} \\
(5.37)\end{array}$ & $\begin{array}{c}0.236 * * * \\
(4.68)\end{array}$ & $\begin{array}{c}0.243^{* * *} \\
(4.80)\end{array}$ & $\begin{array}{c}0.220 * * * \\
(4.49)\end{array}$ & $\begin{array}{c}0.193 * * * \\
(4.01)\end{array}$ & $\begin{array}{c}0.196 * * * \\
(4.04)\end{array}$ \\
\hline Job [dummy] & $\begin{array}{c}-0.0813 \\
(-0.90)\end{array}$ & $\begin{array}{c}-0.0803 \\
(-0.90)\end{array}$ & $\begin{array}{c}-0.0655 \\
(-0.71)\end{array}$ & $\begin{array}{c}0.305^{* * *} \\
(3.58)\end{array}$ & $\begin{array}{c}0.306 * * * \\
(3.61)\end{array}$ & $\begin{array}{c}0.316^{* * *} \\
(3.62)\end{array}$ \\
\hline PercCash [\%] & $\begin{array}{c}0.597^{* * *} \\
(3.61)\end{array}$ & $\begin{array}{c}0.561^{* * *} \\
(3.43)\end{array}$ & $\begin{array}{c}0.542 * * * \\
(3.21)\end{array}$ & $\begin{array}{c}0.355^{* *} \\
(2.42) \\
\end{array}$ & $\begin{array}{c}0.327^{* *} \\
(2.24) \\
\end{array}$ & $\begin{array}{c}0.302^{* *} \\
(1.99) \\
\end{array}$ \\
\hline \multicolumn{7}{|c|}{ Control for human and social capital } \\
\hline AdEq [\#] & $\begin{array}{c}-0.190 * * * \\
(-4.67)\end{array}$ & $\begin{array}{c}-0.191 * * * \\
(-4.74)\end{array}$ & $\begin{array}{c}-0.191 * * * \\
(-4.66)\end{array}$ & $\begin{array}{c}-0.217^{* * *} \\
(-5.80)\end{array}$ & $\begin{array}{c}-0.218 * * * \\
(-5.86)\end{array}$ & $\begin{array}{c}-0.219 * * * \\
(-5.81)\end{array}$ \\
\hline AgeHHH [years] & $\begin{array}{c}0.00600 * \\
(1.92)\end{array}$ & $\begin{array}{c}0.00603^{* *} \\
(1.98)\end{array}$ & $\begin{array}{c}0.00572 * \\
(1.83)\end{array}$ & $\begin{array}{c}0.00739 * * \\
(2.47)\end{array}$ & $\begin{array}{c}0.00742^{* *} \\
(2.50)\end{array}$ & $\begin{array}{c}0.00712^{* *} \\
(2.37)\end{array}$ \\
\hline EducHHH [years] & $\begin{array}{c}0.0142 \\
(1.20)\end{array}$ & $\begin{array}{l}0.0137 \\
(1.16)\end{array}$ & $\begin{array}{c}0.0134 \\
(1.13)\end{array}$ & $\begin{array}{c}0.0313 * * * \\
(2.73)\end{array}$ & $\begin{array}{l}0.0308^{* * *} \\
(2.68)\end{array}$ & $\begin{array}{l}0.0301^{* * *} \\
\quad(2.61)\end{array}$ \\
\hline Ethnicity [dummy] & $\begin{array}{c}0.309 * * \\
(2.44)\end{array}$ & $\begin{array}{c}0.320^{* *} \\
(2.55)\end{array}$ & $\begin{array}{c}0.312^{* *} \\
(2.49)\end{array}$ & $\begin{array}{c}0.283^{* *} \\
(2.40)\end{array}$ & $\begin{array}{c}0.291^{* *} \\
(2.49)\end{array}$ & $\begin{array}{c}0.280^{* *} \\
(2.41)\end{array}$ \\
\hline Female [dummy] & $\begin{array}{c}-0.353^{* *} \\
(-2.18)\end{array}$ & $\begin{array}{c}-0.356^{* *} \\
(-2.19)\end{array}$ & $\begin{array}{c}-0.346 * * \\
(-2.12)\end{array}$ & $\begin{array}{c}-0.402^{* * *} \\
(-2.75)\end{array}$ & $\begin{array}{c}-0.404 * * * \\
(-2.75)\end{array}$ & $\begin{array}{c}-0.397 * * * \\
(-2.71)\end{array}$ \\
\hline EducParents [years] & $\begin{array}{c}0.0266^{*} \\
(1.70)\end{array}$ & $\begin{array}{l}0.0250 \\
(1.60)\end{array}$ & $\begin{array}{l}0.0247 \\
(1.58)\end{array}$ & $\begin{array}{l}0.0214 \\
(1.40)\end{array}$ & $\begin{array}{l}0.0201 \\
(1.32)\end{array}$ & $\begin{array}{c}0.0199 \\
(1.30)\end{array}$ \\
\hline BrothersHHH [\#] & $\begin{array}{c}-0.0305^{*} \\
(-1.83) \\
\end{array}$ & $\begin{array}{c}-0.0312^{*} \\
(-1.89) \\
\end{array}$ & $\begin{array}{c}-0.0300^{*} \\
(-1.80) \\
\end{array}$ & $\begin{array}{c}-0.0345^{* *} \\
(-2.14) \\
\end{array}$ & $\begin{array}{c}-0.0351^{* *} \\
(-2.19) \\
\end{array}$ & $\begin{array}{c}-0.0342^{* *} \\
(-2.14) \\
\end{array}$ \\
\hline \multicolumn{7}{|c|}{ Control for landslide susceptibility and location-specific covariates } \\
\hline Altitude [m.a.s.I.] & $\begin{array}{c}0.000259 \\
(0.29)\end{array}$ & $\begin{array}{c}0.000134 \\
(0.15)\end{array}$ & $\begin{array}{c}0.000230 \\
(0.26)\end{array}$ & $\begin{array}{c}-0.000181 \\
(-0.23)\end{array}$ & $\begin{array}{c}-0.000306 \\
(-0.39)\end{array}$ & $\begin{array}{c}-0.000272 \\
(-0.35)\end{array}$ \\
\hline Buf_Slope $\left[\mathrm{m}^{-2}\right]$ & $\begin{array}{c}-0.0121 \\
(-0.10)\end{array}$ & $\begin{array}{c}0.0134 \\
(0.11)\end{array}$ & $\begin{array}{c}-0.0201 \\
(-0.16)\end{array}$ & $\begin{array}{c}-0.0198 \\
(-0.17)\end{array}$ & $\begin{array}{c}0.00285 \\
(0.02)\end{array}$ & $\begin{array}{c}-0.0154 \\
(-0.13)\end{array}$ \\
\hline Buf_Water $\left[\mathrm{m}^{-2}\right]$ & $\begin{array}{c}0.00300 \\
(1.03)\end{array}$ & $\begin{array}{c}0.00296 \\
(1.02)\end{array}$ & $\begin{array}{c}0.00333 \\
(1.15)\end{array}$ & $\begin{array}{c}0.00414 \\
(1.45)\end{array}$ & $\begin{array}{c}0.00415 \\
(1.47)\end{array}$ & $\begin{array}{c}0.00458 \\
(1.63)\end{array}$ \\
\hline Gneiss [dummy] & $\begin{array}{l}0.583 \\
(1.29)\end{array}$ & $\begin{array}{l}0.470 \\
(1.02)\end{array}$ & $\begin{array}{l}0.533 \\
(1.22)\end{array}$ & $\begin{array}{l}0.550 \\
(1.45)\end{array}$ & $\begin{array}{l}0.459 \\
(1.18)\end{array}$ & $\begin{array}{l}0.515 \\
(1.46)\end{array}$ \\
\hline Mica [dummy] & $\begin{array}{c}0.686^{* * *} \\
(3.01)\end{array}$ & $\begin{array}{c}0.658^{* * *} \\
(3.08)\end{array}$ & $\begin{array}{c}0.656^{* * *} \\
(3.02)\end{array}$ & $\begin{array}{c}0.630 * * * \\
(2.96)\end{array}$ & $\begin{array}{c}0.609 * * * \\
(2.97)\end{array}$ & $\begin{array}{c}0.612^{* * *} \\
(2.93)\end{array}$ \\
\hline -cons & $\begin{array}{c}4.950^{* * *} \\
(3.27)\end{array}$ & $\begin{array}{c}5.253^{* * *} \\
(3.45)\end{array}$ & $\begin{array}{c}5.198^{* * *} \\
(3.42)\end{array}$ & $\begin{array}{c}6.024^{* * *} \\
(4.56)\end{array}$ & $\begin{array}{c}6.297^{* * *} \\
(4.78)\end{array}$ & $\begin{array}{c}6.301^{* * *} \\
(4.84)\end{array}$ \\
\hline Village FE & Yes & Yes & Yes & Yes & Yes & Yes \\
\hline $\mathrm{N}$ & 450 & 450 & 450 & 450 & 450 & 450 \\
\hline$r 2$ & 0.445 & 0.452 & 0.452 & 0.452 & 0.457 & 0.461 \\
\hline $\mathrm{F}$ & 6.897 & 7.187 & 7.053 & 7.575 & 7.839 & 7.940 \\
\hline
\end{tabular}

Interestingly, from equations 2 and 5 in Table 6, total household income is $24 \%$ less affected by landslides than income from agriculture. This suggests that households affected by a landslide seek external income sources in order to compensate for income losses due to landslides. These alternative income sources can be from gifts, monetary or in kind, and transfers or from household members having a job, either self-employed or in wage employment.

A probit regression that estimates how landslides affect the likelihood of having received gifts and transfers in the previous year is given in equation 1 of Table 7, while a probit estimation on how 
landslides affect the likelihood of having a household member with a job is given in equation 2. Having faced a landslide does not seem to affect the likelihood to receive gifts or transfers. This suggests no formal or informal insurance mechanisms are present for landslides in the study area.

During interviews farmers frequently mentioned that doing small jobs for other farmers was a way to earn some money in times of need. Our analysis confirms this, as households that were affected by a landslide in the previous year are significantly more likely to have a household member with a job (Table 7). Yet, from Table 6 we see that these jobs are not sufficient to fully compensate for income losses in agriculture. Households affected more than one year ago are not more likely to have household members with a job.

Table 7: Results of probit estimation with village fixed effects on the likelihood to have received gifts and transfers (1) or to have a household member with a job (2). Ten observations could not be included in the estimation of equation 1 because in one village all 10 households were receiving transfers. $z$ statistics in parentheses. $* p<0.10, * * p<0.05, * * * p<0.01$

\begin{tabular}{|c|c|c|}
\hline Equation number & $(1)$ & $(2)$ \\
\hline Dependent variable & $\begin{array}{c}\text { Gifts or transfers in past } 12 \\
\text { months [Yes }=1]\end{array}$ & $\begin{array}{c}\text { HH member with a job } \\
{[\text { Yes }=1]}\end{array}$ \\
\hline \multicolumn{3}{|l|}{ Experience with landslides } \\
\hline $\begin{array}{l}\% \text { of land affected by LS } \\
0-1 \text { year ago }\end{array}$ & $\begin{array}{c}0.000507 \\
(0.09)\end{array}$ & $\begin{array}{c}0.0128^{*} \\
(1.86) \\
\end{array}$ \\
\hline $\begin{array}{l}\% \text { of land affected by LS } \\
1-2 \text { years ago }\end{array}$ & $\begin{array}{c}-0.00250 \\
(-0.38)\end{array}$ & $\begin{array}{c}0.00723 \\
(1.07)\end{array}$ \\
\hline $\begin{array}{l}\% \text { of land affected by } L S \\
2-4 \text { years ago }\end{array}$ & $\begin{array}{c}0.00203 \\
(0.35) \\
\end{array}$ & $\begin{array}{c}-0.00851 \\
(-1.56) \\
\end{array}$ \\
\hline $\begin{array}{l}\% \text { of land affected by LS } \\
>4 \text { years ago }\end{array}$ & $\begin{array}{l}-0.656 \\
(-1.13)\end{array}$ & $\begin{array}{l}-0.987 \\
(-1.63)\end{array}$ \\
\hline \multicolumn{3}{|c|}{ Control variables on productive capital } \\
\hline TotArea [ha] & $\begin{array}{c}0.248 * * \\
(2.18)\end{array}$ & $\begin{array}{l}0.122 \\
(1.10)\end{array}$ \\
\hline TotPlots [\#] & $\begin{array}{l}0.0173 \\
(0.21)\end{array}$ & $\begin{array}{l}-0.0979 \\
(-1.19)\end{array}$ \\
\hline PercCash [\%] & $\begin{array}{l}0.172 \\
(0.71)\end{array}$ & $\begin{array}{l}-0.314 \\
(-1.25)\end{array}$ \\
\hline \multicolumn{3}{|c|}{ Control for human and social capital } \\
\hline AdEq [\#] & $\begin{array}{c}0.0434 \\
(0.70)\end{array}$ & $\begin{array}{c}0.162 * * \\
(2.57)\end{array}$ \\
\hline AgeHHH [years] & $\begin{array}{c}0.00382 \\
(0.74)\end{array}$ & $\begin{array}{c}-0.0234 * * * \\
(-4.28)\end{array}$ \\
\hline EducHHH [years] & $\begin{array}{c}0.000471 \\
(0.02)\end{array}$ & $\begin{array}{l}0.0763^{* * *} \\
\quad(3.90)\end{array}$ \\
\hline Ethnicity [dummy] & $\begin{array}{c}0.466 * * \\
(2.55)\end{array}$ & $\begin{array}{c}0.375^{* *} \\
(1.98)\end{array}$ \\
\hline Female [dummy] & $\begin{array}{l}-0.217 \\
(-0.83)\end{array}$ & $\begin{array}{l}0.334 \\
(1.33)\end{array}$ \\
\hline EducParents [years] & $\begin{array}{c}0.0215 \\
(0.87)\end{array}$ & $\begin{array}{l}0.0314 \\
(1.28)\end{array}$ \\
\hline BrothersHHH [\#] & $\begin{array}{c}0.000234 \\
(0.01)\end{array}$ & $\begin{array}{c}0.00874 \\
(0.30)\end{array}$ \\
\hline \multicolumn{3}{|c|}{ Control for landslide susceptibility and location-specific covariates } \\
\hline Altitude [m.a.s.l.] & $\begin{array}{c}0.000631 \\
(0.46)\end{array}$ & $\begin{array}{c}0.00248 * \\
(1.70)\end{array}$ \\
\hline Buf_Slope $\left[\mathrm{m}^{-2}\right]$ & $\begin{array}{l}-0.110 \\
(-0.60)\end{array}$ & $\begin{array}{l}-0.268 \\
(-1.35)\end{array}$ \\
\hline Buf_Water $\left[m^{-2}\right]$ & $\begin{array}{c}-0.000738 \\
(-0.18)\end{array}$ & $\begin{array}{c}-0.00316 \\
(-0.70)\end{array}$ \\
\hline Gneiss [dummy] & 0.0287 & -0.0954 \\
\hline
\end{tabular}




\begin{tabular}{|l|cc|} 
& $(0.03)$ & $(-0.12)$ \\
Mica [dummy] & -0.0653 & -0.199 \\
& $(-0.14)$ & $(-0.42)$ \\
\hline _cons & 2.418 & 0.899 \\
& $(1.32)$ & $(0.44)$ \\
Village FE & Yes & Yes \\
\hline $\mathrm{N}$ & 440 & 450 \\
Pseudo $\mathrm{r2}$ & 0.1358 & 0.2107 \\
Wald Chi2 & 85.07 & 129.13 \\
\hline
\end{tabular}

\section{Discussion}

The approach described in this manuscript illustrates how the combination of a cross-sectional household survey with geographical information at household level can be used to quantify the direct impact of landslides on household livelihoods in tropical mountainous regions. We have shown that it is important to control for slope steepness, geology and other geographical factors at household level, as well as for measures of productive, human and social capital.

We did not explicitly investigate the effect of the geographical variables on landslide susceptibility and on household income. However, we controlled for differences in geology, runoff accumulation and geographical factors such as altitude and slope in the regressions. If we had not controlled for these geographical factors, an endogeneity issue would have made it impossible to attribute the difference in income between affected and unaffected households to the occurrence of landslides. The mere presence of landslide risk could have affected this difference, as well as other processes, e.g. soil erosion by water and tillage, probably correlated with both landslide occurrence and household income. By controlling for the geographical factors we ensured that the direct impact of landslides on household income was estimated.

The validity of our estimations crucially rests upon the correct specification of our regression models. Throughout the analysis we adopted a one-step approach, whereby we estimated the impact of landslide occurrence while at the same time controlling for landslide risk. To confirm the validity of this approach we also estimated the impact of landslides with a two-step approach, called treatment effects estimation. In the first step of this approach we used a probit regression to estimate the likelihood to be affected by a landslide for each household. In the second step we estimated the average impact of landslide occurrence, or the average treatment effect, by comparing the income of affected households with the income of unaffected households, while controlling for the households' likelihood to be affected by a landslide. The results of this estimation (depicted in Table A2 of the Appendix) confirmed the validity of our models, as a similar impact of landslides was found.

While our approach proved suitable for the estimation of the direct impact of recent landslides on household income, making conclusions on the long-term impact of landslides was more difficult. The sample design, whereby the village chairmen were initially asked whether a household was affected by a landslide or not, induced a strong bias towards more recent landslides. With our data it was hard to assess whether the impact of landslides was indeed not significant when more than four years had passed since the landslide occurred, or whether this was due to incomplete information on these landslides. While the advantage of a cross-sectional survey is its relative speed and low cost, time series panel data would be more appropriate to estimate the long-term consequences of landslides. 


\section{Conclusions and recommendations}

The results of the case study in the Rwenzori region suggest that landslides do seriously affect the livelihoods of the farmers in the study area. More than $20 \%$ of all households in the sampled villages have experienced a landslide on one of their plots in the past 15 years. These households lost a significant percentage of their income from agriculture in the year of a landslide occurrence. The findings indicate that the income losses due to landslides forced the household members to seek for alternative income sources, thereby providing an illustration of the impact of landslides on households' livelihoods.

An average loss of $20 \%$ was measured for income from agriculture, while an average loss of $15 \%$ was measured for total income. These are large numbers, which are particularly relevant because most households in our study area live in a precarious situation, with $90 \%$ of the households being multidimensional poor. It should therefore not come as a surprise that $64 \%$ of the affected households mentioned that they had faced hunger after the landslide occurred.

The severity of the impact on household income is highly dependent on the percentage of the land affected by a landslide. It is therefore likely that households with more land or with many plots are more resilient towards landslides than households which have less land. These findings confirm and expand previous qualitative literature on the impact of landslides in Sub-Saharan Africa (e.g. Msilimba, 2009; Mugagga, 2011).

In an attempt to compensate for income losses after a landslide, household members sought for selfemployed activities or wage labour on other farms. The income obtained from these jobs did not fully compensate for income losses due to landslides, as total household income remained significantly affected by landslides. We found that members of households that had been affected by a landslide more than one year ago were not more likely to have a job than members of unaffected households. This suggests that jobs were abandoned once the emergency situation after the landslide had been cleared.

We did not find indications of increasing transfers or remittances after a landslide, suggesting that no formal or informal insurance mechanisms were present for landslides in the region. While remittances are considered to be an important method for households to reduce the impact of income shocks in developing countries (Azam \& Gubert, 2006), the households in our sample did not seem to make use of such a strategy after landslides.

In summary, landslides have a significant effect on income from agriculture and on total household income in the Rwenzori region. Households with more plots are likely to be more resilient towards landslides and affected households seek income sources outside agriculture to compensate for income losses after the occurrence of a landslide. No formal or informal risk sharing mechanism seems to be present for landslides in the study area.

Based on these findings, two recommendations are made for the reduction of landslide impact on household income in the Rwenzori region. First, providing more attractive and sustainable jobs outside agriculture could increase the resilience towards landslides in the region. Currently the attractiveness of the jobs is likely to be low, as they are abandoned once the immediate need for money after a landslide has passed.

Secondly, as the burden of landslides is significant and the coping strategies adopted by the households do not seem sufficient to avoid severe income losses, the development of local risk-sharing mechanisms should be promoted. Local disaster relief funds or credit and saving mechanisms at village level could be established with the explicit purpose to provide relief after landslides. To adequately 
target support it is necessary to develop clear criteria for identifying the households that are most severely affected. While this was not the objective of the current study, the findings suggest that households with less and smaller plots were more likely to be severely affected.

As this paper presented the impact of landslides on household income in a tropical mountainous regions, its findings and recommendations are relevant to similar regions with a high landslide hazard. It was shown how a combination of geographical data and information on natural hazards and socioeconomic characteristics at household level can be used to estimate the impact of landslides on household income. By quantifying this impact in a remote region this study draws the attention towards a problem that has been broadly underestimated so far and provides relevant input for policy makers and development institutions.

\section{Acknowledgment}

This study would not have been possible without the financial support of the AfReSlide project, BR/121/A2/AfReSlide, entitled 'Landslides in Equatorial Africa: Identifying culturally, technically and economically feasible resilience strategies' and funded by the Belgian Science Policy (BELSPO), nor without the support of the VLIR UOS South Initiative, ZEIN2013Z145, entitled 'Diagnosis of land degradation processes, their socio-economical and physical controls and implications in the Mt Rwenzori region'. The generous logistic support provided by the Mountains of the Moon University is also highly appreciated. Finally, we would like to thank the enumerators for their intense work in the mountains, as well as the many village chiefs and household heads who readily shared their time and knowledge with us.

\section{References}

1. Alimohammadlou, Y., Najafi, A., \& Yalcin, A. (2013). Landslide process and impacts: A proposed classification method. Catena, 104, 219-232. http://doi.org/10.1016/j.catena.2012.11.013

2. Alkire, S., Roche, J. M., Santos, M. E., \& Seth, S. (2011). Multidimensional Poverty Index 2011: Brief Methodological Note. Oxford Poverty and Human Development Initiative Publication.

3. Arouri, M., Nguyen, C., \& Youssef, A. Ben. (2015). Natural Disasters, Household Welfare, and Resilience: Evidence from Rural Vietnam. World Development, 70, 59-77. http://doi.org/10.1016/j.worlddev.2014.12.017

4. Azam, J.-P., \& Gubert, F. (2006). Migrants' Remittances and the Household in Africa: A Review of Evidence. Journal of African Economies, 15(Supplement 2), 426-462. http://doi.org/10.1093/jae/ejl030

5. Cameron, L., \& Shah, M. (2015). Risk-Taking Behavior in the Wake of Natural Disasters. Journal of Human Resources, 50(2), 484-515. Retrieved from http://www.nber.org/papers/w19534

6. Claessens, L., Knapen, A., Kitutu, M. G., Poesen, J., \& Deckers, J. A. (2007). Modelling landslide hazard, soil redistribution and sediment yield of landslides on the Ugandan footslopes of Mount Elgon. Geomorphology, 90, 23-35. http://doi.org/10.1016/j.geomorph.2007.01.007

7. Corominas, J., van Westen, C., Frattini, P., Cascini, L., Malet, J. P., Fotopoulou, S., ... Smith, J. T. (2014). Recommendations for the quantitative analysis of landslide risk. Bulletin of Engineering Geology and the Environment, 73(2), 209-263. http://doi.org/10.1007/s10064-013-0538-8

8. Crovelli, R. a., \& Coe, J. a. (2009). Probabilistic estimation of numbers and costs of future landslides in the San Francisco Bay region. Georisk: Assessment and Management of Risk for Engineered Systems and Geohazards, 3(4), 206-223. http://doi.org/10.1080/17499510802713123

9. Cruden, D. M., \& Varnes, D. J. (1996). Landslide types and processes. In A. Turner \& R. Schuster (Eds.), Landslides: Investigation and Mitigation. (pp. 36-75). Transportation Research Board, National 631 Research Council.

10. Cutter, S. L., Barnes, L., Berry, M., Burton, C., Evans, E., Tate, E., \& Webb, J. (2008). A place-based 
model for understanding community resilience to natural disasters. Global Environmental ChangeHuman and Policy Dimensions, 18, 598-606. http://doi.org/10.1016/j.gloenvcha.2008.07.013

11. Dai, F. ., Lee, C. ., \& Ngai, Y. . (2002). Landslide risk assessment and management: an overview. Engineering Geology, 64(1), 65-87. http://doi.org/10.1016/S0013-7952(01)00093-X

12. De Haen, H., \& Hemrich, G. (2007). The economics of natural disasters: implications and challenges for food security. Agricultural Economics, 37(August), 31-45. http://doi.org/10.1111/j.15740862.2007.00233.x

13. Deaton, A. (1997). The analysis of household surveys: a microeconometric approach to development policy. Vasa. World Bank Publications. Retrieved from http://elibrary.worldbank.org/doi/abs/10.1596/0-8018-5254-4

14. Dercon, S. (2006). Vulnerability: a micro perspective. Securing Development in an Unstable World, 30, 117-146. Retrieved from http://books.google.com/books?hl=en\&lr=\&id=2RDB5gOLsr4C\&oi=fnd\&pg=PA117\&dq=Vulnerab ility+:+a+micro+perspective\&ots=Kvtos3RfVz\&sig=ROuS4MpL3ejYXOmd-YkOWt06PJ4

15. ESRI. (2015). ArcGIS Desktop: Release 10.2 Redlands, CA: Environmental Systems Research Institute.

16. Glade, T. (2003). Vulnerability assessment in landslide risk analysis. Erde, 134, 123-146.

17. Gloede, O., Menkhoff, L., \& Waibel, H. (2015). Shocks, Individual Risk Attitude, and Vulnerability to Poverty among Rural Households in Thailand and Vietnam. World Development, 71, 54-78. http://doi.org/10.1016/j.worlddev.2013.11.005

18. Glynn, A. N., \& Quinn, K. M. (2010). An Introduction to the Augmented Inverse Propensity Weighted Estimator. Political Analysis, 18(1), 36-56. http://doi.org/10.1093/pan/mpp036

19. GTK Consortium. (2012). Geological map of Uganda 1:100,000 Sheet $\mathrm{N}^{\circ} 65$ Karambi.

20. Hulme, D., \& Shepherd, A. (2003). Conceptualizing Chronic Poverty. World Development, 31(3), 403-423. http://doi.org/10.1016/S0305-750X(02)00222-X

21. Jacobs, L., Dewitte, O., Poesen, J., Delvaux, D., Thiery, W., \& Kervyn, M. (2015). The Rwenzori Mountains, a landslide-prone region? Landslides. http://doi.org/10.1007/s10346-015-0582-5

22. Jacobs, L., Dewitte, O., Poesen, J., Sekajugo, J., Maes, J., Mertens, K., ... Kervyn, M. (2015). Landslide characteristics and spatial distribution in the Rwenzori Mountains, Uganda. Submitted to Journal of African Earth Sciences, 1-9.

23. Jaedicke, C., Van Den Eeckhaut, M., Nadim, F., Hervás, J., Kalsnes, B., Vangelsten, B. V., ... Smebye, H. (2013). Identification of landslide hazard and risk "hotspots" in Europe. Bulletin of Engineering Geology and the Environment, 73(2), 325-339. http://doi.org/10.1007/s10064-013-0541-0

24. Kahn, M. (2005). The death toll from natural disasters: the role of income, geography, and institutions. Review of Economics and Statistics. Retrieved from http://www.mitpressjournals.org/doi/abs/10.1162/0034653053970339

25. Kervyn, M., Bih Che, V., de Hontheim, A., Dewitte, O., Isabirye, M., Jacobs, L., ... Vranken, L. (n.d.). Landslides resilience in Equatorial Africa: Moving beyond the problem identification. Submitted to BELGEO.

26. Kitutu, M. G., Muwanga, A., Poesen, J., \& Deckers, J. A. (2011). Farmer's perception on landslide occurrences in Bududa District, Eastern Uganda. African Journal of Agricultural Research, 6, 7-18. Retrieved from $<$ Go to $|S|>: / /$ WOS:000287927200002

27. Klose, M., Highland, L., Damm, B., \& Terhorst, B. (2014). Estimation of Direct Landslide Costs in Industrialized Countries: Challenges, Concepts, and Case Study. In Landslide Science for a Safer Geoenvironment (Vol. 2, pp. 661-667). Cham: Springer International Publishing. http://doi.org/10.1007/978-3-319-05050-8_103

28. Knapen, A., Kitutu, M. G., Poesen, J., Breugelmans, W., Deckers, J., \& Muwanga, A. (2006). Landslides in a densely populated county at the footslopes of Mount Elgon (Uganda): characteristics and causal factors. Geomorphology, 73, 149-165.

29. Lacasse, S., \& Nadim, F. (2009). Landslide Risk Assessment and Mitigation Strategy. In K. Sassa \& P. Canuti (Eds.), Landslides - Disaster Risk Reduction (pp. 31-61). Springer Berlin Heidelberg. http://doi.org/10.1007/978-3-540-69970-5_3 
30. Mendelsohn, R., \& Saher, G. (2010). The Global Impact of Climate Change on Extreme Events. Background Paper for the WB/UN Report "Natural Hazards, Unnatural Disasters," (May), 1-42.

31. Meyer, V., Becker, N., Markantonis, V., Schwarze, R., van den Bergh, J. C. J. M., Bouwer, L. M., ... Viavattene, C. (2013). Review article: Assessing the costs of natural hazards - state of the art and knowledge gaps. Natural Hazards and Earth System Sciences, 13(5), 1351-1373. http://doi.org/10.5194/nhess-13-1351-2013

32. Msilimba, G. G. (2009). The socioeconomic and environmental effects of the 2003 landslides in the Rumphi and Ntcheu Districts (Malawi). Natural Hazards, 53(2), 347-360. http://doi.org/10.1007/s11069-009-9437-5

33. Mugagga, F. (2011). Land use change, landslide occurrence and livelihood strategies on mount elgon slopes, eastern uganda. Nelson Mandela Metropolitan University.

34. Mugagga, F., Buyinza, M., \& Kakembo, V. (2010). Livelihood diversification strategies and soil erosion on Mount Elgon, Eastern Uganda: A socio-economic perspective. Environmental Research .... Retrieved from http://www.medwelljournals.com/fulltext/?doi=erj.2010.272.280

35. Ngecu, W. M., Nyamai, C. M., \& Erima, G. (2004). The extent and significance of mass-movements in Eastern Africa: case studies of some major landslides in Uganda and Kenya. Environmental Geology, 46, 1123-1133. http://doi.org/10.1007/s00254-004-1116-y

36. Okuyama, Y., \& Sahin, S. (2009). Impact Estimation of Disasters A Global Aggregate for 1960 to 2007. Policy Research Working Paper, The World Bank, 4963.

37. Petley, D. (2012). Global patterns of loss of life from landslides. Geology, 40(10), 927-930. http://doi.org/10.1130/G33217.1

38. Petrucci, O., \& Gullà, G. (2009). A simplified method for assessing landslide damage indices. Natural Hazards, 52(3), 539-560. http://doi.org/10.1007/s11069-009-9398-8

39. Rose, A. (2004). Defining and measuring economic resilience to disasters. Disaster Prevention and Management, 13(4), 307-314. http://doi.org/10.1108/09653560410556528

40. Sen, A. (2001). Development as Freedom (2nd ed.). New York: Oxford University Press.

41. Stata Press. (2013). STATA TREATMENT-EFFECTS REFERENCE MANUAL : POTENTIAL OUTCOMES / COUNTERFACTUAL OUTCOMES Release 13.

42. StataCorp. (2015). Stata Statistical Software: Release 14. College Station, TX: StataCorp LP.

43. Taylor, R. G., Mileham, L., Tindimugaya, C., \& Mwebembezi, L. (2009). Recent glacial recession and its impact on alpine riverflow in the Rwenzori Mountains of Uganda. Journal of African Earth Sciences, 55(3-4), 205-213. http://doi.org/10.1016/j.jafrearsci.2009.04.008

44. Thanapackiam, P., Khairulmaini, O. S., \& Fauza, a. G. (2012). Vulnerability and adaptive capacities to slope failure threat: a study of the Klang Valley Region. Natural Hazards, 62(3), 805-826. http://doi.org/10.1007/s11069-012-0108-6

45. The World Bank. (2000). Designing household survey: Questionnaires for developing countries. Retrieved from https://openknowledge.worldbank.org/bitstream/handle/10986/15195/multi_page.pdf?sequen ce $=1$

46. The World Bank. (2015). Ugandan Purchasing Power Parity. Retrieved June 16, 2015, from http://data.worldbank.org/indicator/PA.NUS.PPP

47. Toya, H., \& Skidmore, M. (2007). Economic development and the impacts of natural disasters. Economics Letters, 94(1), 20-25. http://doi.org/10.1016/j.econlet.2006.06.020

48. UBOS. (2014). 2014 Population and Housing Census: preparatory files for planning. Kampala, Uganda.

49. UNDP. (2014). Uganda Poverty Status Report 2014. Ministry of Finance, Planning and Economic Development, (November).

50. UNISDR. (2015). Making Development Sustainable: The Future of Disaster Risk Management. Global Assessment Report on Disaster Risk Reduction. Geneva, Switzerland.

51. USGS. (2014). Shuttle Radar Topography Mission, 1 Arc second scenes SRTM1N00E030V3, SRTM1N00E029V3, SRTM1S01E030V3, SRTM1S01E029V3, Unfilled Unfinished, Global Land Cover Facility, University of Maryland, College Park, Maryland, February 2000. 
52. Vranken, L., Van Turnhout, P., Van den Eeckhaut, M., Vandekerckhove, L., \& Poesen, J. (2013). Economic valuation of landslide damage in hilly regions: A case study from Flanders, Belgium. Science of the Total Environment, 447, 323-336. http://doi.org/10.1016/j.scitotenv.2013.01.025

53. Wisner, B. (2001). Capitalism and the shifting spatial and social distribution of hazard and vulnerability. Australian Journal of Emergency Management, 16(2), 44-50. Retrieved from http://search.informit.com.au/documentSummary; $d n=378174191869592 ;$ res=IELHSS

54. Wisner, B., Blaikie, P., Cannon, T., \& Davis, I. (2003). At risk: natural hazards, people's vulnerability and disasters (Part 1). In At risk: natural hazards, people's vulnerability and disasters (p. 134).

55. Wolfe, B. L., \& Behrman, J. R. (1984). Who is schooled in developing countries? The roles of income, parental schooling, sex, residence and family size. Economics of Education Review, 3(3), 231-245. http://doi.org/10.1016/0272-7757(84)90036-0

\section{Appendix}

The results of reduced form regressions of the OLS regressions presented in the manuscript are displayed in Table A1. Results are very similar to the results which include all covariates, illustrating the robustness of the analysis.

Table A1: Results of the reduced form Ordinary Least Square (OLS) regressions with village fixed effects on income per adult equivalent per day from agriculture (1-3) or total income per adult equivalent per day (4-6). $t$ statistics in parentheses. $* \mathrm{p}<0.10, * * \mathrm{p}<0.05, * * * \mathrm{p}<0.01$

\begin{tabular}{|c|c|c|c|c|c|c|}
\hline Equation number & (1) & (2) & (3) & (4) & (5) & (6) \\
\hline Dependent variable & $\begin{array}{l}\text { Log(Income } \\
\text { agriculture) }\end{array}$ & $\begin{array}{l}\text { Log(Income } \\
\text { agriculture) }\end{array}$ & $\begin{array}{l}\text { Log(Income } \\
\text { agriculture) }\end{array}$ & Log(Income) & Log(Income) & Log(Income) \\
\hline \multicolumn{7}{|c|}{ Experience with landslides } \\
\hline LS & $\begin{array}{l}-0.178^{*} \\
(-1.84)\end{array}$ & & & $\begin{array}{l}-0.158^{*} \\
(-1.70)\end{array}$ & & \\
\hline $\begin{array}{l}\text { \% of land affected by } \\
\text { most recent LS }\end{array}$ & & $\begin{array}{c}-0.00978 * * * \\
(-3.67)\end{array}$ & & & $\begin{array}{c}-0.00824 * * * \\
(-3.18)\end{array}$ & \\
\hline $\begin{array}{l}\% \text { of land affected by } \\
\text { LS } 0-1 \text { year ago }\end{array}$ & & & $\begin{array}{c}-0.00925^{* *} \\
(-2.33)\end{array}$ & & & $\begin{array}{c}-0.00675^{*} \\
(-1.80)\end{array}$ \\
\hline $\begin{array}{l}\% \text { of land affected by } \\
\text { LS } 1-2 \text { years ago }\end{array}$ & & & $\begin{array}{c}-0.00873^{* *} \\
(-2.28)\end{array}$ & & & $\begin{array}{c}-0.00552^{*} \\
(-1.65)\end{array}$ \\
\hline $\begin{array}{l}\% \text { of land affected by } \\
\text { LS } 2-4 \text { years ago }\end{array}$ & & & $\begin{array}{c}-0.00739 \\
(-1.54) \\
\end{array}$ & & & $\begin{array}{c}-0.00877^{* *} \\
(-1.98) \\
\end{array}$ \\
\hline $\begin{array}{l}\% \text { of land affected by } \\
\text { LS }>4 \text { years ago }\end{array}$ & & & $\begin{array}{l}0.127 \\
(0.34)\end{array}$ & & & $\begin{array}{l}0.0279 \\
(0.08)\end{array}$ \\
\hline \multicolumn{7}{|c|}{ Control variables on productive capital } \\
\hline TotArea & $\begin{array}{c}0.330 * * * \\
(4.65)\end{array}$ & $\begin{array}{c}0.307^{* * *} \\
(4.57)\end{array}$ & $\begin{array}{c}0.292^{* * *} \\
(4.31)\end{array}$ & $\begin{array}{c}0.257^{* * *} \\
(4.25) \\
\end{array}$ & $\begin{array}{c}0.237^{* * *} \\
(4.11)\end{array}$ & $\begin{array}{c}0.223^{* * *} \\
(3.82)\end{array}$ \\
\hline \multicolumn{7}{|c|}{ Control for human and social capital } \\
\hline _cons & $\begin{array}{c}6.699 * * * \\
(23.34)\end{array}$ & $\begin{array}{c}6.764 * * * \\
(22.67)\end{array}$ & $\begin{array}{c}6.817^{* * *} \\
(22.16)\end{array}$ & $\begin{array}{c}7.145^{* * *} \\
(25.34)\end{array}$ & $\begin{array}{c}7.197 * * * \\
(24.36)\end{array}$ & $\begin{array}{c}7.240 * * * \\
(23.09)\end{array}$ \\
\hline Village FE & Yes & Yes & Yes & Yes & Yes & Yes \\
\hline $\mathrm{N}$ & 450 & 450 & 450 & 450 & 450 & 450 \\
\hline r2 & 0.324 & 0.343 & 0.346 & 0.303 & 0.319 & 0.322 \\
\hline $\mathrm{F}$ & 15.020 & 15.270 & 14.712 & 7.503 & 7.790 & 7.475 \\
\hline
\end{tabular}

The results of the treatment-effects estimation with augmented inverse probability weighting are displayed in Table A2. This treatment estimation model uses a probit regression to estimate the likelihood to be treated i.e. the likelihood to be affected by a landslide. The specification of this probit model is similar to the model presented in Equation 1, except that the variables Job and PerCash have been omitted. As these variables are modified by the occurrence of a landslide, they cannot be used to estimate the likelihood to be treated. A linear model is subsequently used to estimate the impact of the treatment on households' income. This linear model makes use of the same variables as Equation 1, including Job and PerCash, but takes into account the estimated likelihood to be affected 
(i.e. by the results of the probit estimates). Both estimations use sub-county fixed-effects, rather than village fixed-effects, to allow the common support hypothesis to hold.

Table A2. Result of the treatment-effects estimation with augmented inverse probability weighting on income per adult equivalent per day from agriculture (1) and total income per adult equivalent per day (2). $z$ statistics in parentheses. * $p<$ $0.10, * * p<0.05, * * * p<0.01$

\begin{tabular}{|c|c|c|c|}
\hline \multicolumn{2}{|l|}{ Equation } & (1) & (2) \\
\hline \multicolumn{2}{|l|}{ Dependent variable } & $\begin{array}{l}\text { Log(Income } \\
\text { Agriculture) }\end{array}$ & Log(Income) \\
\hline \multicolumn{2}{|c|}{$\begin{array}{l}\text { Average Treatment Effect (ATE) of a } \\
\text { landslide }\end{array}$} & $\begin{array}{c}-0.16 \\
(-1.91)^{*}\end{array}$ & $\begin{array}{l}-0.11 \\
(-1.47)\end{array}$ \\
\hline \multirow{2}{*}{$\begin{array}{l}\text { Over-identification test } \\
\text { on balanced covariates }\end{array}$} & Chi2(21) & 3.87 & 3.87 \\
\hline & Prob > chi2 & 1 & 1 \\
\hline \multicolumn{2}{|l|}{ Observations } & 450 & 450 \\
\hline
\end{tabular}

